\title{
Determining the effect of natural inhibitors on sesame meal degradability using in vitro three step method
}

\author{
Maghsoud Besharati ${ }^{1 *}$, Valiollah Palangi², Akbar Taghizadeh ${ }^{3}$, Adem Kaya ${ }^{2}$, \\ and Soheila Abachi ${ }^{4}$ \\ ${ }^{1}$ Department of Animal Science, Ahar Faculty of Agriculture and Natural Resources, University of Tabriz, 51666, \\ Tabriz, Iran \\ ${ }^{2}$ Department of Animal Science, Agricultural Faculty, Ataturk University, Erzurum, Turkey \\ ${ }^{3}$ Department of Animal Science, Faculty of Agriculture, University of Tabriz, Tabriz, Iran \\ ${ }^{4}$ Institute of Nutrition and Functional Foods (INAF), Université Laval, Quebec City, Quebec, Canada
}

BeSharati, M., V. Palangi, A. TAghizadeH, A. KAYA, S. ABACHI: Determining the effect of natural inhibitors on sesame meal degradability by using in vitro three step method. Vet. arhiv 91, 513-521, 2021.

\section{ABSTRACT}

The aim of this experiment was to investigate the beneficial effect of monensin, tannic acid and cinnamon essential oil addition on sesame meal degradability by the three-step in vitro method. The effect of experimental additives on the degradability of sesame meal in the rumen, after rumen and in the whole gastrointestinal tract was significant $(\mathrm{P}<0.05)$. The in vitro ruminal and intestinal digestibility of sesame meal crude protein with experimental additives was in the range of 76 to $84 \%$ and 49 to $60 \%$, respectively. The intestinal degradability of crude protein increased with the addition of cinnamon essential oil (about 10\%). Addition of monensin, tannic acid, and cinnamon essential oil significantly increased the degradability of Neutral Detergent Fiber (NDF) and Acid Detergent Fiber (ADF) in the rumen, intestines and the whole gastrointestinal tract. The results showed that cinnamon essential oil (125 mg/L) increased the degradability of dry matter (DM), organic matter (OM), crude protein (CP), ADF and NDF in the rumen, after rumen and the whole digestive tract compared to all treatments $(\mathrm{P}<0.05)$. The results showed that addition of tannic acid $(100 \mathrm{mg} / \mathrm{L})$ decreased the disappearance of crude protein in the rumen, while it increased crude protein's disappearance in the after rumen $(\mathrm{P}<0.05)$.

Key words: monensin; tannic acid; cinnamon essential oil; sesame meal; three step degradability

\section{Introduction}

Agricultural by-products such as sesame meal can have a major impact on reducing production costs (OBEIDAT et al., 2019; MISHRA et al., 2019). Sesame meal is a by-product of the sesame oil manufacturing, containing about $46 \%$ crude protein. Not only could this proteinaceous by- product replace soy as a protein supplement in animal nutrition but could also reduce the increasing cost of feed (GHORBANI et al., 2018). In ruminants, feed efficiency is low due to ruminal fermentation and gas production (OWENS and BASALAN, 2016; KARLSSON et al., 2019).

\footnotetext{
*Corresponding author:

Dr. Maghsoud Besharati, Department of Animal Science, Ahar Faculty of Agriculture and Natural Resources, University of Tabriz, 29 ${ }^{\text {th }}$ Bahman Blv., 51666, Tabriz, Iran, E-mail: m_besharati@hotmail.com
} 
Methane production is directly related to feed consumption, and about $2-12 \%$ of the feed's raw energy is lost as methane production (TAPIO et al., 2017). Although the use of antibiotics increases feed efficiency, due to the creation of drug-resistant bacteria this class of compounds have been banned in the EU as growth promoters. Today, other additives such as herbal essential oils are safe natural alternatives used for this purpose (HUANG et al., 2018; LILLEHOJ et al., 2018). Natural essential oils and tannic acid have successfully been used to reduce methane production, ruminal protein decomposition and ammonia production, and increase ruminal protein for further digestion in the gut, improving ruminal fermentation efficiency (CAROPRESE et al., 2020). In a study, researchers reported oxygen monoterpenes (especially alcohols) and monoterpene aldehydes among the chemical compounds of essential oils, as potent biomolecules manipulating the growth and metabolism of ruminal microbes. On the other hand, monoterpene hydrocarbons have fewer inhibitory effects and sometimes stimulate microbial activity (BENCHAAR et al., 2008). Overall, essential oils have a great effect on the activity of ruminal microorganisms and can improve energy and nitrogen consumption in the rumen (COBELLIS et al., 2016; RIBEIRO et al., 2020). Cinnamon is a plant whose stem extracts, young shoots and leaves are used medicinally. One of the major active ingredients in cinnamon essential oil is cinnamaldehyde. Cinnamaldehyde, a compound of the phenylpropanoid class with strong antimicrobial activity, is the most abundant compound (about $75 \%$ ) of cinnamon essential oil (RIBEIRO-SANTOS et al., 2017; LEE et al., 2020). The aim of this experiment was to investigate the effect of monensin, tannic acid and cinnamon essential oil on sesame meal degradability using a three-step method (GARGALLO et al., 2006).

\section{Material and methods}

The chemical composition of sesame meal, including dry matter (DM), ether extract (EE), crude ash (CA), acid detergent insoluble fiber (ADF) and neutral detergent fiber (NDF), were determined according to the proposed AOAC (2005) methods.
Crude protein was measured using a Kjeldahl analyzer (Foss Tecator AB analyzer, Hoganas, Swede Kjeltec 2300 Auto analyzer) according to the AOAC standard method (AOAC, 2005). The results are presented in Table 1.

Table 1. Chemical composition of sesame meal (\%)

\begin{tabular}{|l|c|}
\hline Chemical composition & $\%$ \\
\hline DM & 93.21 \\
\hline CA & 9.93 \\
\hline OM & 90.07 \\
\hline CF & 14.30 \\
\hline CP & 40.95 \\
\hline NDF & 41.50 \\
\hline ADF & 18.40 \\
\hline Hemicellulose & 23.10 \\
\hline
\end{tabular}

DM, dry matter; CP, crude protein; NDF, neutral detergent fiber; ADF, acid detergent fiber; CA: crude ash; OM: organic matter; $\mathrm{CF}$ : crude fat.

Additives used and chemical analyses of essential oil. Cinnamon essential oil extraction was performed according to the standard method by water distillation using Clevenger apparatus (JAHANI-AZIZABADI et al., 2011). For this purpose, cinnamon was ground to fine particles and then $70 \mathrm{~g}$ of the sample was placed into the balloon of the Clevenger apparatus and $750 \mathrm{~mL}$ of distilled water was added to each balloon. It was then boiled for 3.5 hours. After this period, the essential oil was collected at the appropriate location in sterile glass (JAHANI-AZIZABADI et al., 2011). The cinnamon essential oils were characterized by GCMS. For GC-MS analysis, an Agilent 7890B gas chromatograph with a $30 \mathrm{~m}$ to $0.25 \mathrm{~mm}$ HP-5MS capillary column, coupled with an Agilent 5973 mass spectrometer (Agilent Technologies, Palo Alto, CA) operating in EI mode at $70 \mathrm{eV}$ were used. The temperatures of the injector and detector ports were set at 250 and $150^{\circ} \mathrm{C}$ respectively. Initially, the column temperature was held at $60^{\circ} \mathrm{C}$ for $3 \mathrm{~min}$ and then increased at a rate of $5{ }^{\circ} \mathrm{C} / \mathrm{min}$ to $220^{\circ} \mathrm{C}$. The temperature of column was held at $220^{\circ} \mathrm{C}$ for $10 \mathrm{~min}$. The composition of cinnamon essential oil is shown in Table $2.72 .32 \%$ cinnamaldehyde content of cinnamon was obtained. 
Table 2. Composition of Cinnamon essential oil

\begin{tabular}{|l|c|c|}
\hline Composition & & Percentage \\
\hline Styrene & $\mathrm{C}_{8} \mathrm{H}_{8}$ & 0.55 \\
\hline Benzaldehyde & $\mathrm{C}_{7} \mathrm{H}_{6} \mathrm{O}$ & 1.31 \\
\hline Cinnamaldehyde & $\mathrm{C}_{9} \mathrm{H}_{8} \mathrm{O}$ & 72.32 \\
\hline Cinnamyl alcohol & $\mathrm{C}_{9} \mathrm{H}_{10} \mathrm{O}$ & 0.10 \\
\hline 1-Naphthol & $\mathrm{C}_{10} \mathrm{H}_{8} \mathrm{O}$ & 0.13 \\
\hline Benzylideneacetone & $\mathrm{C}_{10} \mathrm{H}_{10} \mathrm{O}$ & 3.20 \\
\hline Cuminaldehyde & $\mathrm{C}_{10} \mathrm{H}_{12} \mathrm{O}$ & 0.69 \\
\hline Carveol & $\mathrm{C}_{10} \mathrm{H}_{16} \mathrm{O}$ & 3.17 \\
\hline Borneol & $\mathrm{C}_{10} \mathrm{H}_{18} \mathrm{O}$ & 0.16 \\
\hline Benzene 1,5-dimethyl & $\mathrm{C}_{15} \mathrm{H}_{22}$ & 1.21 \\
\hline Nonylphenol & $\mathrm{C}_{15} \mathrm{H}_{24}$ & 14.17 \\
\hline
\end{tabular}

Samples of oven-dried sesame meal were ground with a mill so that the particle diameter was equal to $1 \mathrm{~mm}$. Dacron bags $(12 \times 10 \mathrm{~cm}$ with a $50 \pm 10$ micron porosity) were dried in an oven at $65{ }^{\circ} \mathrm{C}$ and heated to a constant weight. The bags were then placed into a desiccator and the sesame meal samples were poured into the bags. They were completely sealed using a plastic sewing machine. The other additives used in this experiment were monensin $\left(\right.$ Monencivet $^{\mathbb{}}$ ) and tannic acid (Merck GmbH, Darmstadt, Germany).

In vitro experimental design. In order to determine the effect of various additives on the degradability of sesame meal, GARGALO et al's (2006) method was used using a Daisy ${ }^{I I}$ incubator

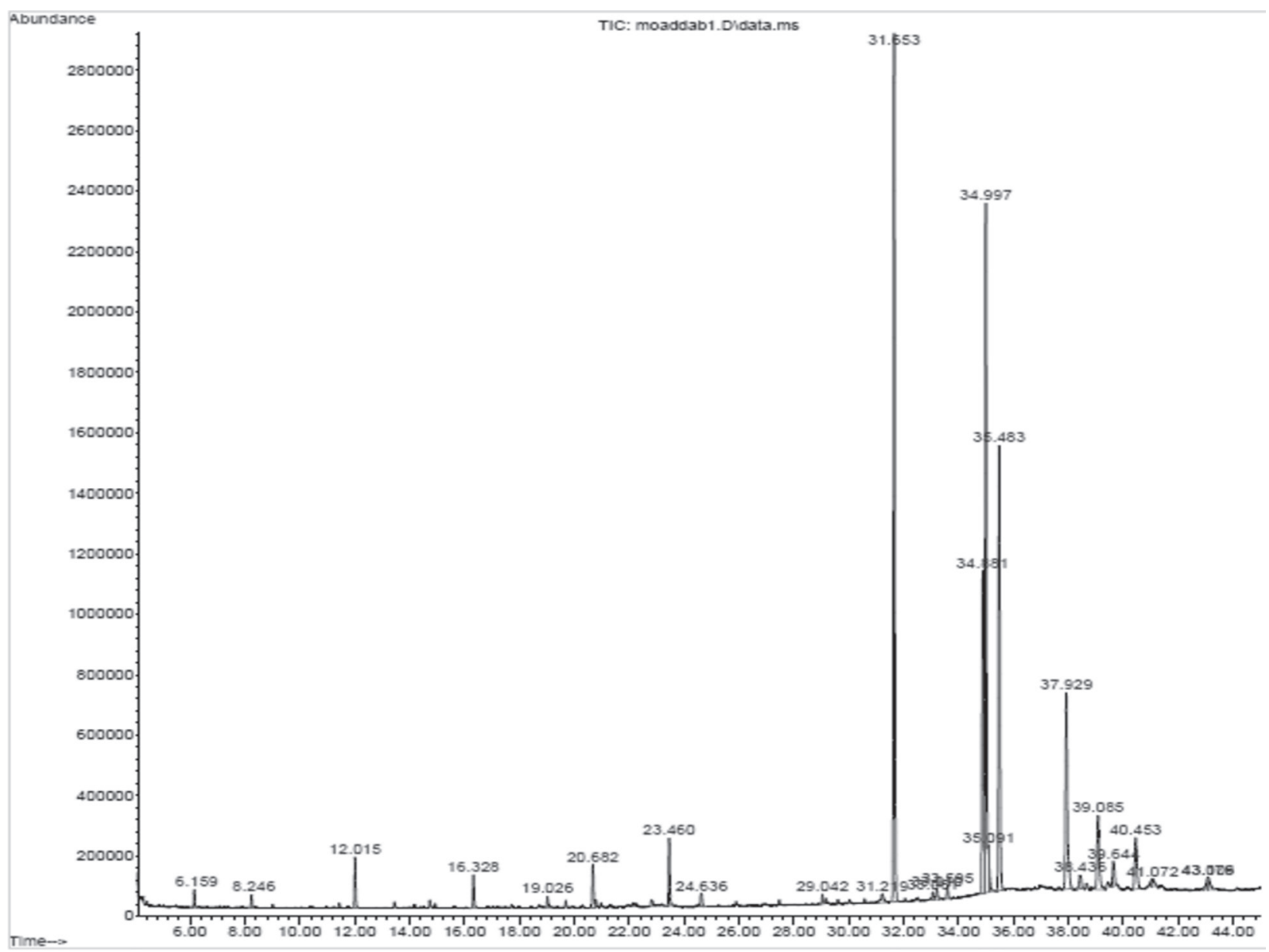

Fig 1. The graph of GC-mas of cinnamon essential oil 
(Ankom, Fairport, NY). In this experiment, about $3 \mathrm{~g}$ of the sample were poured into Dacron bags and sewn with heat. Nine bags for each treatment were placed into a bottle containing a buffer prepared by BESHARATI et al. (2020) and rumen liquid (2:1). The buffer solution was flushed with $\mathrm{CO}_{2}$ to remove the oxygen. The rumen liquid was prepared from 3 sheep from a slaughterhouse after slaughter. The samples were incubated inside the Daisy for 16 hours at $39^{\circ} \mathrm{C}$. After incubation, they were removed from the bottle and rinsed with cold water for 15 minutes. They were placed in an oven at $55^{\circ} \mathrm{C}$ for 48 hours. After drying, DM, OM and CP digestibility were measured according to the AOAC (2005) methods.

The pepsin-pancreatin procedure of CALSAMIGLIA and STERN (1995) was conducted with $15 \mathrm{~mL}$ of a solution containing high enzymatic activity pepsin (P-7012, Sigma, St. Louis, MO). The 6 bags containing ruminal digested samples were placed inside each jar, and were kept for 1 hour at $39{ }^{\circ} \mathrm{C}$. Then, the bags were kept in jars containing pancreatin solution for 24 hours at $39^{\circ} \mathrm{C}$. After incubation, the bags were taken out of the jars and washed. The bags were dried in the oven at 55 ${ }^{\circ} \mathrm{C}$ for 48 hours and then weighed.

Using the following equation, the percentage of sample digestibility was calculated:

$\%$ Dig $=\frac{(\mathrm{W} 1-\mathrm{W} 2)}{\mathrm{Wm}} \times 100$

where,

W1: Bag and sample weight before digestion

W2: Weight of the bag and sample after digestion Wm: Sample Weight (g)

Run 1:

Experimental treatments included: sesame meal (control), sesame meal $+12 \mathrm{mg}$ monensin/L medium, sesame meal+500 mg tannic acid/ L medium, sesame meal $+150 \mathrm{mg}$ cinnamon essential oil/ L medium.

Run 2:

Experimental treatments included: sesame meal (control), sesame meal $+24 \mathrm{mg}$ monensin/L medium, sesame meal+1000 mg tannic acid/ L medium, sesame meal $+250 \mathrm{mg}$ cinnamon essential oil/ L medium.
Statistical analysis. The data obtained were analyzed as a completely randomized design using a GLM procedure of SAS (2018), with Duncan's multiple range test used for comparison of means. Additives (cinnamon oil, monensin and tannic acid) were the only sources of variation considered (PALANGI and MACIT, 2019). The following mathematical model was used for statistical analysis.

$$
\mathrm{Y}_{\mathrm{ijk}}=\mu+\mathrm{T}_{\mathrm{i}+} \mathrm{e}_{\mathrm{ij}}
$$

where $\mathrm{Y}_{\mathrm{ij}}$ represents dependent variable; $\mu$ the general mean; $T_{i}$ is the effect of treatment (additives); $\mathrm{e}_{\mathrm{ij}}$ is error.

\section{Results and discussion}

The chemical composition of sesame meal is given in Table 1. The tested sesame meal contained $40.95 \%$ CP, which was higher than the values reported by other researchers (GHORBANI et al., 2018; OMER et al., 2019).The effect of adding monensin $(12 \mathrm{mg} / \mathrm{L})$, tannic acid $(500 \mathrm{mg} / \mathrm{L})$ and cinnamon essential oil $(125 \mathrm{mg} / \mathrm{L})$ on the three-step degradability of sesame meal using GARGALLO et al. (2006) method is given in Table 3. The results showed that the values of digestibility of all parameters measured throughout the gastrointestinal tract, the rumen and intestines were different. In the present study, the in vitro ruminal, intestinal and total GI tract DM digestibility values were affected by experimental treatments, and the difference between the means was statistically significant.

According to the results of this study, the disappearance of in vitro ruminal and intestinal organic matter was affected by the experimental treatments, where the highest amount was related to the treatment containing cinnamon essential oil $(125 \mathrm{mg} / \mathrm{L})$. Organic matter degradability in the total tract in the treatments with monensin, tannic acid and cinnamon essential oil showed the highest rate of organic matter degradation, with a significant difference compared to the control $(\mathrm{P}<0.05)$. The digestibility of in vitro ruminal and intestinal sesame meal $\mathrm{CP}$, with the addition of monensin, tannic acid and cinnamon essential oil, were in the range of 76 to $84 \%$ and 49 to $60 \%$, respectively. 
Table 3. Evaluation of the effect of adding low levels of monensin, tannic acid and cinnamon essential oil on the degradability kinetics of sesame meal in a three-step method

\begin{tabular}{|l|c|c|c|c|c|c|}
\hline Treatments & 1 & 2 & 3 & 4 & SEM & P-Value \\
\hline Ruminal degradability \\
\hline DM & $67.94^{\mathrm{c}}$ & $75.71^{\mathrm{b}}$ & $82.09^{\mathrm{a}}$ & $84.56^{\mathrm{a}}$ & 1.610 & $<0.0001$ \\
\hline OM & $70.03^{\mathrm{c}}$ & $75.74^{\mathrm{b}}$ & $81.92^{\mathrm{a}}$ & $84.42^{\mathrm{a}}$ & 1.729 & $<0.0001$ \\
\hline CP & $76.69^{\mathrm{b}}$ & $84.69^{\mathrm{a}}$ & $87.10^{\mathrm{a}}$ & $85.56^{\mathrm{a}}$ & 1.234 & $<0.0001$ \\
\hline ADF & $73.27^{\mathrm{c}}$ & $80.74^{\mathrm{b}}$ & $88.50^{\mathrm{a}}$ & $90.13^{\mathrm{a}}$ & 2.014 & $<0.0001$ \\
\hline NDF & $82.27^{\mathrm{d}}$ & $86.00^{\mathrm{c}}$ & $91.17^{\mathrm{b}}$ & $94.02^{\mathrm{a}}$ & 0.957 & $<0.0001$ \\
\hline \multicolumn{7}{|l|}{} \\
\hline Intestinal degradability & $11.43^{\mathrm{c}}$ & $16.22^{\mathrm{b}}$ & $19.74^{\mathrm{b}}$ & $21.53^{\mathrm{a}}$ & 0.871 & $<0.0001$ \\
\hline DM & $12.86^{\mathrm{c}}$ & $16.95^{\mathrm{b}}$ & $21.80^{\mathrm{b}}$ & $24.13^{\mathrm{a}}$ & 0.861 & $<0.0001$ \\
\hline OM & $50.72^{\mathrm{b}}$ & $47.78^{\mathrm{c}}$ & $49.34^{\mathrm{b}}$ & $59.48^{\mathrm{a}}$ & 0.374 & $<0.0001$ \\
\hline CP & $13.82^{\mathrm{c}}$ & $19.48^{\mathrm{b}}$ & $22.60^{\mathrm{a}}$ & $23.95^{\mathrm{a}}$ & 0.829 & $<0.0001$ \\
\hline ADF & $11.56^{\mathrm{c}}$ & $24.17^{\mathrm{a}}$ & $20.20^{\mathrm{b}}$ & $24.25^{\mathrm{a}}$ & 0.844 & $<0.0001$ \\
\hline NDF & $73.72^{\mathrm{b}}$ & $82.73^{\mathrm{a}}$ & $90.26^{\mathrm{a}}$ & $90.23^{\mathrm{a}}$ & 0.381 & $<0.0001$ \\
\hline Total tract degradability & $72.75^{\mathrm{b}}$ & $82.90^{\mathrm{a}}$ & $87.48^{\mathrm{a}}$ & $90.46^{\mathrm{a}}$ & 0.275 & $<0.0001$ \\
\hline DM & $82.14^{\mathrm{b}}$ & $93.21^{\mathrm{a}}$ & $94.48^{\mathrm{a}}$ & $95.28^{\mathrm{a}}$ & 0.114 & $<0.0001$ \\
\hline OM & $77.18^{\mathrm{c}}$ & $86.84^{\mathrm{b}}$ & $92.37^{\mathrm{ab}}$ & $93.95^{\mathrm{a}}$ & 0.047 & $<0.0001$ \\
\hline CP & $75.58^{\mathrm{c}}$ & $91.00^{\mathrm{b}}$ & $93.46^{\mathrm{ab}}$ & $96.35^{\mathrm{a}}$ & 0.384 & $<0.0001$ \\
\hline ADF & &
\end{tabular}

Differences between the averages indicated by different letters in the same row are important. Treatments: 1 - Sesame meal (control), 2 - Sesame meal + $24 \mathrm{mg} / 1$ Monensin, 3 - Sesame meal $+1000 \mathrm{mg} / 1$ tannic acid, 4 - Sesame meal + $250 \mathrm{mg} / \mathrm{L} \mathrm{cinnamon}$ essential oil

The results indicate that addition of cinnamon essential oil increased the intestinal CP degradability by about $10 \%$. The addition of monensin, tannic acid, and cinnamon essential oil significantly increased the degradability of ADF and NDF in the rumen, intestine, and total tract, which was further observed in the treatment containing cinnamon essential oil. In a study conducted by YANG et al. (2010) supplementing different levels of cinnamaldehyde (400, 800, $1600 \mathrm{mg} /$ day) using an in situ method, they reported that at levels 400 and $800 \mathrm{mg}$, the ruminal biodegradability of $\mathrm{OM}$ increased compared to the control, but by increasing the cinnamaldehyde level to $1600 \mathrm{mg} / \mathrm{day}$, the ruminal biodegradability of OM decreased, which was consistent with the results of our study. Also, an increase in the amount of cinnamaldehyde led to a decrease in ruminal NDF degradability. However, the degradability of organic matter and NDF in the post-rumen (intestinal) was not affected by the increase in cinnamaldehyde content. OSBORNE et al. (2004) examined $22 \mathrm{mg} / \mathrm{kg}$ DM of monensin supplementation using 2 fistulas of Holstein cows. They found that ruminal DM, CP, ADF, NDF degradability was not affected by the addition of monensin, but total tract degradability increased compared to the control, which is consistent with the results of the present experiment. In another study, BENCHAAR et al. (2008) evaluated monensin $(16 \mathrm{mg} / \mathrm{kg} \mathrm{DM})$ and essential oil (a mixture of thymol, eugenol, and limonene at 2 $\mathrm{g}$ per day) supplementation on soybean meal using Breastfeeding Holstein cows, and found that DM, OM, and NDF digestibility throughout the gastrointestinal tract was not affected by experimental treatments, which does not match the results of the present experiment. 
The effect of adding monensin $(24 \mathrm{mg} / \mathrm{L})$, tannic acid $(1000 \mathrm{mg} / \mathrm{L})$ and cinnamon essential oil (250 $\mathrm{mg} / \mathrm{L})$ on the three-step degradability of sesame meal using GARGALLO et al. (2006) method is shown in Table 3. In the present study, adding monensin, tannic acid and cinnamon essential oil to sesame meal significantly increased the DM, $\mathrm{CP}, \mathrm{OM}, \mathrm{ADF}$ and $\mathrm{NDF}$ in vitro ruminal, intestinal and total tract degradability, and this increase on degradability in the rumen was greater than in the intestine. The values of in vitro ruminal, intestinal, and total tract degradability tested parameters did not significantly differ between treatments containing monensin and cinnamon essential oil, but the differences were significant compared to tannic acid treatments. However, in the intestine, treatments containing tannic acid and cinnamon essential oil had a higher CP degradability compared to monensin treatments. Our results differed from those of BENCHAAR et al. (2008), who reported that adding thymol $(200 \mathrm{mg} / \mathrm{L})$, carvacrol (400 $\mathrm{mg} / \mathrm{L})$ and eugenol $(800 \mathrm{mg} / \mathrm{L})$ would reduce crude fiber. This may be due to the fact that they used active ingredients instead of using essential oils, which resulted in improved effects. An increase in DM degradability may be considered as a positive effect of cinnamon essential oil, because in most studies the use of essential oils has led to a decrease in DM degradability, which is an adverse effect of the use of herbal essential oils (COBELLIS et al., 2016; ELWAKEEL et al., 2019; DAVOODI et al., 2019). An increase in DM degradability is highly desirable in terms of nutrition, and an increase in CP degradability can be considered as one of the negative effects of using cinnamon essential oil, because it reduces the efficiency of nitrogen

Table 4. Evaluation of the effect of adding high levels of monensin, tannic acid and cinnamon essential oil on the degradability kinetics of sesame meal in a three-step method

\begin{tabular}{|l|c|c|c|c|c|c|}
\hline Treatments & 1 & 2 & 3 & 4 & SEM & P-Value \\
\hline Ruminal degradability & \multicolumn{7}{|l|}{} \\
\hline DM & $56.55^{\mathrm{c}}$ & $74.82^{\mathrm{a}}$ & $63.64^{\mathrm{b}}$ & $71.24^{\mathrm{a}}$ & 1.281 & $<0.0001$ \\
\hline OM & $57.90^{\mathrm{d}}$ & $78.29^{\mathrm{a}}$ & $64.37^{\mathrm{c}}$ & $71.72^{\mathrm{b}}$ & 1.245 & $<0.0001$ \\
\hline CP & $66.62^{\mathrm{d}}$ & $83.77^{\mathrm{a}}$ & $70.87^{\mathrm{c}}$ & $77.34^{\mathrm{b}}$ & 1.001 & $<0.0001$ \\
\hline ADF & $61.72^{\mathrm{c}}$ & $84.87^{\mathrm{a}}$ & $71.01^{\mathrm{b}}$ & $84.25^{\mathrm{a}}$ & 0.954 & $<0.0001$ \\
\hline NDF & $74.58^{\mathrm{c}}$ & $85.62^{\mathrm{ab}}$ & $86.38^{\mathrm{a}}$ & $83.89^{\mathrm{b}}$ & 0.604 & $<0.0001$ \\
\hline \multicolumn{7}{|l|}{} \\
\hline Intestinal degradability & $13.83^{\mathrm{c}}$ & $29.76^{\mathrm{ab}}$ & $26.78^{\mathrm{b}}$ & $33.54^{\mathrm{a}}$ & 1.479 & $<0.0001$ \\
\hline DM & $14.23^{\mathrm{c}}$ & $33.00^{\mathrm{a}}$ & $28.48^{\mathrm{b}}$ & $34.33^{\mathrm{a}}$ & 1.422 & $<0.0001$ \\
\hline OM & $50.94^{\mathrm{d}}$ & $54.44^{\mathrm{c}}$ & $61.99^{\mathrm{a}}$ & $57.73^{\mathrm{b}}$ & 0.625 & $<0.0001$ \\
\hline CP & $14.21^{\mathrm{c}}$ & $33.20^{\mathrm{ab}}$ & $30.02^{\mathrm{b}}$ & $36.42^{\mathrm{a}}$ & 0.914 & $<0.0001$ \\
\hline ADF & $11.99^{\mathrm{c}}$ & $40.51^{\mathrm{a}}$ & $26.95^{\mathrm{b}}$ & $37.42^{\mathrm{a}}$ & 0.804 & $<0.0001$ \\
\hline NDF & $73.72^{\mathrm{b}}$ & $82.73^{\mathrm{a}}$ & $90.26^{\mathrm{a}}$ & $90.23^{\mathrm{a}}$ & 1.560 & $<0.0001$ \\
\hline Total tract degradability & $72.75^{\mathrm{b}}$ & $82.90^{\mathrm{a}}$ & $87.48^{\mathrm{a}}$ & $90.46^{\mathrm{a}}$ & 1.492 & $<0.0001$ \\
\hline DM & $82.14^{\mathrm{b}}$ & $93.21^{\mathrm{a}}$ & $94.48^{\mathrm{a}}$ & $95.28^{\mathrm{a}}$ & 0.676 & $<0.0001$ \\
\hline OM & $77.18^{\mathrm{c}}$ & $86.84^{\mathrm{b}}$ & $92.37^{\mathrm{ab}}$ & $93.95^{\mathrm{a}}$ & 1.041 & $<0.0001$ \\
\hline CP & $75.58^{\mathrm{c}}$ & $91.00^{\mathrm{b}}$ & $93.46^{\mathrm{ab}}$ & $96.35^{\mathrm{a}}$ & 0.702 & $<0.0001$ \\
\hline ADF
\end{tabular}

Differences between the averages indicated by different letters in the same row are important. Treatments: 1- Sesame meal (control), 2- Sesame meal + $24 \mathrm{mg} / 1$ Monensin, 3- Sesame meal + $1000 \mathrm{mg} / 1$ tannic acid, 4- Sesame meal + $250 \mathrm{mg} / 1$ cinnamon essential oil. 
use, and reduces the amount of protein passing into the intestine. The essential oils and natural extracts of medicinal plants have antimicrobial properties (AUMEERUDDY-ELALFI et al., 2016; MOUSSAOUI and ALAOUI, 2016; SAKKAS and PAPADOPOULOU, 2017), therefore, they may be used as alternatives to ruminal fermentation enhancers due to their ability to improve energy efficiency and protein utilization. There is a direct relationship between the ruminal DM and OM disappearance with the VFA production, and increasing or decreasing the rate of disappearance have affected the ruminal VFA production (SARMADI et al., 2016; CHOWDHURY et al., 2018; SALAS et al., 2019).

\section{Conclusion}

Adding Cinnamon essential oil increased the disappearance of in vitro ruminal and intestinal organic matter. Overall, the additives used in this study increased the total tract degradability of sesame meal in comparison with the control.

\section{Conflict of interest}

The authors declare that they have no known compering financial interests or personal relationship that could appear to have influenced the work reported in this paper.

\section{Acknowledgements}

We thank the Iran National Science Foundation for supporting of this project.

\section{References}

AOAC 2005: Official Methods of Analysis of AOAC international. AOAC international. Maryland, USA.

AUMEERUDDY-ELALFI, Z., A. GURIB-FAKIM, M. F. MAHOMOODALLY (2016): Chemical composition, antimicrobial and antibiotic potentiating activity of essential oils from 10 tropical medicinal plants from Mauritius. J. Herb. Med. 6, 88-95.

DOI: 10.1016/j.hermed.2016.02.002

BENCHAAR, C., T. MCALLISTER, P. CHOUINARD (2008): Digestion, ruminal fermentation, ciliate protozoal populations, and milk production from dairy cows fed cinnamaldehyde, quebracho condensed tannin, or Yucca schidigera saponin extracts. J. Dairy Sci. 91, 4765-4777.

DOI: $10.3168 /$ jds.2008-1338

BESHARATI, M., V. PALANGI, M. MOADDAB, Z. NEMATI, A. B. PLIEGO, A. Z. SALEM (2020): Influence of cinnamon essential oil and monensin on ruminal biogas kinetics of waste pomegranate seeds as a biofriendly agriculture environment. Waste. Biomass. Valori. 1-10.

DOI: $10.1007 / \mathrm{s} 12649-020-01167-2$

CALSAMIGLIA, S., D. STERN (1995): A three step in vitro procedure for estimating intestinal digestion of protein in ruminants. J. Anim. Sci. 73, 1459-1465.

CAROPRESE, M., M. G. CILIBERTI, M. ALBENZIO (2020): Application of aromatic plants and their extracts in dairy animals. In Feed Additives Academic Press. pp. 261-277. DOI: 10.1016/B978-0-12-814700-9.00015-7

CHOWDHURY, M. R., M. M. H. KHAN, S. U. MAHFUZ, M. A. BASET (2018): Effects of dietary supplementation of spices on forage degradability, ruminal fermentation, in vivo digestibility, growth performance and nitrogen balance in Black Bengal goat. J. Anim. Physiol. Anim. Nut. 102(2), e591-e598.

DOI: $10.1111 /$ jpn. 12800

COBELliS, G., M. TRABALZA-MARINUCCI, Z. YU (2016): Critical evaluation of essential oils as rumen modifiers in ruminant nutrition: A review. Sci. Total Environ. 545, 556-568.

DOI: 10.1016/j.scitotenv.2015.12.103

DAVOODI, S. M., M. D. MESGARAN, A. R. VAKILI, R. VALIZADEH, A. G. PIRBALOUTI (2019): In vitro effect of essential oils on rumen fermentation and microbial nitrogen yield of high concentrate dairy cow diet. Biosci. Biotech. Res. Asia. 16, 333-341.

DOI: $10.13005 /$ bbra/2749

ELWAKEEL, E. A., A. A. AL-SAGHEER, M. G. AHMED (2019): Evaluation of the effect of four essential oils as potential alternatives for monensin on rumen fermentation characteristics and nutrient degradability. Egyptian J. Nut. Feeds. 22, 43-54.

DOI: $10.21608 /$ ejnf.2019.79414

GARGAllO, S., S. CALSAMigLiA, A. FERRET (2006): A modified three-step in vitro procedure to determine intestinal digestion of proteins. J. Anim. Feed Sci. 84: 2163-2167.

DOI: $10.2527 /$ jas.2004-704

GHORBANI, B., A. T. YANSARI, A. J. SAYYADI (2018): Effects of sesame meal on intake, digestibility, rumen characteristics, chewing activity and growth of lambs. South African J. Anim. Sci. 48, 151-161.

DOI: $10.4314 /$ sajas.v48i1.17

HUANG, Q., X. LIU, G. ZHAO, T. HU, Y. WANG (2018): Potential and challenges of tannins as an alternative to infeed antibiotics for farm animal production. Anim. Nut. 4, 137-150.

DOI: 10.1016/j.aninu.2017.09.004

JAHANI-AZIZABADI, H., M., MESGARAN, A. VAKILI, K. REZAYAZDI, M. HASHEMI (2011): Effect of various medicinal plant essential oils obtained from semiarid climate on rumen fermentation characteristics of a 
high forage diet using in vitro batch culture. African $\mathrm{J}$. Microbiol. Res. 5, 4812-4819.

DOI: $10.5897 / A J M R 11.575$

KARLSSON, J., M. RAMIN, M. KASS, M. LINDBERG, K. HOLTENIUS (2019): Effects of replacing wheat starch with glycerol on methane emissions, milk production, and feed efficiency in dairy cows fed grass silage-based diets. J. Dairy Sci. 102, 7927-7935.

DOI: $10.3168 /$ jds.2018-15629

LEE, J. E., M. JUNG, S.C. LEE, M. J. HUH, S. M. SEO, I. K. PARK (2020): Antibacterial mode of action of trans-cinnamaldehyde derived from cinnamon bark (Cinnamomum verum) essential oil against Agrobacterium tumefaciens. Pesticide Biochem. Physiol. 104546.

DOI: 10.1016/j.pestbp.2020.02.012

LILLEHOJ, H., Y. LIU, S. CALSAMIGLIA, M. E. FERNANDEZ-MIYAKAWA, F. CHI, R. L. CRAVENS, C. G. GAY (2018): Phytochemicals as antibiotic alternatives to promote growth and enhance host health. Vet. Res. 49, 76.

DOI: $10.1186 / \mathrm{s} 13567-018-0562-6$

MISHRA, B., S. VARJANI, G. K. S. VARMA (2019): Agroindustrial by-products in the synthesis of food grade microbial pigments: An eco-friendly alternative. In Green Bio-processes. Springer, Singapore, pp. 245-265.

DOI: $10.1007 / 978-981-13-3263-0 \quad 13$

MOUSSAOUI, F., T. ALAOUI (2016): Evaluation of antibacterial activity and synergistic effect between antibiotic and the essential oils of some medicinal plants. Asian Pacific J. Trop. Biomed. 6, 32-37.

DOI: $10.1016 /$ j.apjtb.2015.09.024

OBEIDAT, B. S., R.T. KRIDLI, K.Z. MAHMOUD, M.D. OBEIDAT, S.G. HADDAD, H.S. SUBIH, J.M. ALKHAZÁLEH (2019): Replacing Soybean Meal with Sesame Meal in the Diets of Lactating Awassi Ewes Suckling Single Lambs: Nutrient Digestibility, Milk Production, and Lamb Growth. Animals. 9, 157.

DOI: 10.3390/ani9040157

OMER, H. A. A., S. M. AHMED, S. S. ABDEL-MAGID, B. A. BAKRY, M. F. EL-KARAMANY, E. H. EL-SABAAWY (2019): Nutritional impact of partial or complete replacement of soybean meal by sesame (Sesamum indicum) meal in lambs rations. Bulletin National Res. Cent. 43, 98.

DOI: $10.1186 / \mathrm{s} 42269-019-0140-8$

OSBORNE, J., T. MUTSVANGWA, O. ALZAHAL, T. DUFFIELD, R. BAGG, P. DICK, G. VESSIE, B. MCBRIDE (2004): Effects of monensin on ruminal forage degradability and total tract diet digestibility in lactating dairy cows during grain-induced subacute ruminal acidosis. J. Dairy Sci. 87, 1840-1847.

DOI: $10.3168 /$ jds.S0022-0302(04)73341-X

OWENS, F. N., M. BASALAN (2016): Ruminal fermentation. In: Rumenology, Springer, Cham. pp. 63-102.

DOI: 10.1007/978-3-319-30533-2_3

PALANGI, V., M. MACIT (2019): In situ crude protein and dry matter ruminal degradability of heat-treated barley. Rev. Méd. Vét. 170, 123-128.

RIBEIRO, A. D. B., M. V. C. FERRAZ JUNIOR, D. M. POLIZEL, A. A. MISZURA, J. P. R. BARROSO, A. R. CUNHA, A.V. PIRES (2020): Effect of thyme essential oil on rumen parameters, nutrient digestibility, and nitrogen balance in wethers fed high concentrate diets. Arq. Bras. Med. Vet. Zoo. 72, 573-580.

DOI: $10.1590 / 1678-4162-11322$

RIBEIRO-SANTOS, R., M. ANDRADE, N.R. DE MELO, F.R. DOS SANTOS, I. DE ARAÚJO NEVES, M.G. DE CARVALHO, A. SANCHES-SILVA (2017): Biological activities and major components determination in essential oils intended for a biodegradable food packaging. Indust. Crops Prod. 97, 201-210.

DOI: 10.1016/j.indcrop.2016.12.006

SAKKAS, H., C. PAPADOPOULOU (2017): Antimicrobial activity of basil, oregano, and thyme essential oils. J. Microbiol. Biotechnol. 27, 429-438.

DOI: $10.4014 / \mathrm{jmb} .1608 .08024$

SALAS, H., L. CASTILLEJOS, M. LÓPEZ-SUÁREZ, A. FERRET (2019): In vitro digestibility, in situ degradability, rumen fermentation and $\mathrm{N}$ metabolism of camelina coproducts for beef cattle studied with a dual flow continuous culture system. Animals, 9, 1079.

DOI: $10.3390 /$ ani9121079

SARMADI, B., Y. ROUZBEHAN, J. REZAEI (2016) Influences of growth stage and nitrogen fertilizer on chemical composition, phenolics, in situ degradability and in vitro ruminal variables in amaranth forage. Anim. Feed Sci. Technol. 215, 73-84

DOI: $10.1016 /$ j.anifeedsci.2016.03.007

SAS (2018): Institute Inc. SAS/CONNECT ${ }^{\circledR} 9.4$ User’s Guide. Fourth Edition. Cary. NC: SAS Institute Inc.

TAPIO, I., T. J. SNELLING, F. STROZZI, R. J. WALLACE (2017): The ruminal microbiome associated with methane emissions from ruminant livestock. J. Anim. Sci. Biotechnol. 8, 7.

DOI: $10.1186 / \mathrm{s} 40104-017-0141-0$

YANG, W., B. AMETAJ, C. BENCHAAR, K. BEAUCHEMIN (2010): Dose response to cinnamaldehyde supplementation in growing beef heifers: ruminal and intestinal digestion. J. Anim. Sci. 88, 680-688.

DOI: $10.2527 /$ jas.2008-1652 
BESharaTi, M., V. PALANGI, A. TAGHIZADEH, A. KAYA, S. ABACHI: Istraživanje učinka prirodnih inhibitora na razgradivost sezama primjenom in vitro metode u tri koraka. Vet. arhiv 91, 513-521, 2021.

\section{SAŽETAK}

Cilj ovog rada bio je istražiti pozitivni učinak dodatka monenzina, tanina i esencijalnog ulja cimeta na razgradivost sezama in vitro metodom u tri koraka. Pronađen je znakovit učinak pokusnih dodataka na razgradivost sezama $\mathrm{u}$ buragu, a zatim i u cijelom gastrointestinalnom traktu $(\mathrm{P}<0,05)$. In vitro buražna i intestinalna probavljivost sirovih bjelančevina sezama s pokusnim dodacima bila je od 76 do 84 \%, odnosno 49 do $60 \%$. Intestinalna razgradivost sirove bjelančevine povećala se s dodatkom esencijalnog ulja cimeta (oko 10 \%). Dodatak monenzina, tanina i esencijalnog ulja cimeta znakovito je povećao razgradivost neutralnih vlakana deterdženta (NDF) i kiselih vlakana deterdženta (ADF) u buragu, crijevima i cijelom gastrointestinalnom traktu. Rezultati su pokazali da esencijalno ulje cimeta (125 $\mathrm{mg} / \mathrm{L})$ povećava razgradivost suhe tvari (DM), organske tvari (OM), sirovog proteina (CP), ADF-a i NDF-a u buragu, a zatim i u cijelom probavnom sustavu u usporedbi s drugim pokusnim postupcima $(\mathrm{P}<0,05)$. Rezultati su pokazali da dodatak tanina (100 mg/L) smanjuje razgradnju sirovog proteina u buragu, a povećava njegovu razgradnju u dijelu probavnog trakta nakon buraga $(\mathrm{P}<0,05)$.

Ključne riječi: monenzin; tanin; esencijalno ulje cimeta; sezamovo brašno; razgradnja u tri koraka 
